\title{
Development of health technology assessment in Central Europe
}

doi:10.1017/S0266462309990547

To the Editor:

Once upon a time in the 1990s, if you wanted to do HTA in the Central and Eastern European countries (CEEs), you got yourself invited by Egon Jonsson and travelled to Stockholm to learn how to do HTA. There you met him and Prof. Banta and other HTA professionals from all over the world - very importantly, motivated healthcare professionals from all CEEs who were eager to learn HTA. These eminent founding fathers were always available, and were never tired if help or assistance was needed. During that time, the telephone number of HTA was known and used extensively, making it a real, living, informal HTA network. Formal HTA collaborations organized by them and funded by the European Commission, such as EUR-ASSESS, HTA EUROPE, ECHTA/ECAHI, were also crucial ...

Therefore, we read with great interest the series of excellent papers on the review of HTA history in different countries and on international level (International Society for Technology Assessment in Health Care and Health Technology Assessment International; International Journal of Technology Assessment in Health Care) $(2 ; 3 ; 24)$. This special issue of the International Journal of Technology Assessment in Health Care provides a comprehensive overview of activities in and development of HTA in the past decades.

As it is described in the journal, although development of health technology assessment was difficult in any country, former socialist countries of Eastern-Europe had to face special challenges (21). During the series of healthcare reforms and economic transitions, the Hungarian healthcare system faced two different challenges: the rising health expenditures resulted in a pressure of cutting the budget on the one hand, and the growing demands and needs of patients on the other. For many years, a simple fiscal answer tried to soften the problems focusing mainly on the expenditure side. In the past years, when HTA became more and more stronger and embedded in Hungary, health technology assessment became a promising tool in healthcare decision making.
We should emphasize the role of international organizations in the development of HTA in Hungary. As an outstanding achievement of local efforts and international support (a World Bank loan), a Health Services Management Training Center at the Semmelweis University in Budapest and a School of Public Health at the University of Debrecen was established in the middle of 1990s, both serving as an important academic institution for healthcare policy makers and hospital managers not only in Hungary but also in Central and Eastern Europe. The Health Evidence Network (HEN) of the World Health Organization (WHO) had also significant effect on the development of Hungarian HTA.

Another important milestone of HTA development in Hungary was the inclusion of HTA into the governmental decision-making process of pharmaceutical reimbursement after 1 May 2004, when Hungary joined to European Union. Although submission of an HTA report is not compulsory in Hungary in course of application for health insurance reimbursement, a health technology assessment report can provide valuable information for health insurance decision makers and can strengthen the application dossier.

The current research topics in Hungary-in line with the international literature $(17 ; 18 ; 23 ; 26)$ —covers, for example, osteoporosis and arthritis (14-16;27;28), oncology and cancer screening $(4 ; 5 ; 9-13 ; 25)$, healthcare financing $(1 ; 6-8)$, and coverage policy $(19 ; 20 ; 22)$. In addition to the universities and research centers, the Hungarian National Health Insurance Fund Administration (Országos Egészségbiztosítási Pénztár, OEP) played an active role in the publication of scientific papers in the field of HTA.

Finally, we would like to highlight the important role of Professors Egon Jonsson and David Banta in the worldwide development of HTA in the past decades, with special respect to their commitment to the introduction, development, and permeation of HTA in Hungary.

\section{REFERENCES}

1. Akkazieva B, Gulacsi L, Brandtmuller A, Pentek M. Bridges J. Patients' preferences for healthcare system reforms in 
Hungary: A conjoint analysis. Appl Health Econ Health Policy. 2006;5:189-198.

2. Banta D, Jonsson E, Childs P. History of the international societies in health technology assessment: International Society for Technology Assessment in Health Care and Health Technology Assessment International. Int J Technol Assess Health Care. 2009;25(Suppl 1):19-23.

3. Banta D, Jonsson E. History of HTA: Introduction. Int J Technol Assess Health Care. 2009;25(Suppl 1):1-6.

4. Boncz I. Organized nationwide breast cancer screening programme was introduced in Hungary in 2002. Swiss Med Wkly. 2006; $136: 328$.

5. Boncz I. Prevention of cervical cancer in low-resource settings. JAMA. 2006;295:1248.

6. Boncz I, Sebestyen A. Economy and mortality in Eastern and Western Europe between 1945-1990: The largest medical trial of history. Int J Epidemiol. 2006;35:796-797.

7. Boncz I, Sebestyen A. Financial deficits in the health services of the UK and Hungary. Lancet. 2006;368:917-918.

8. Boncz I, Nagy J, Sebestyen A, Korosi L. Financing of health care services in Hungary. Eur J Health Econ. 2004;5:252-258.

9. Boncz I, Sebestyen A, Dobrossy L, Otto S. The role of immunochemical testing for colorectal cancer. Lancet Oncol. 2006; 7:363-364.

10. Boncz I, Sebestyen A, Dobrossy L, et al. The organization and results of first screening round of the Hungarian nationwide organised breast cancer screening programme. Ann Oncol. 2007; 18:795-799.

11. Boncz I, Sebestyen A, Ember I. Organized, nationwide cervical cancer screening programme in Hungary. Gynecol Oncol. 2007; 106:272-273.

12. Boncz I, Sebestyen A, Pinter I, Battyany I, Ember I. The effect of an organized, nationwide breast cancer screening programme on non-organized mammography activities. J Med Screen. 2008;15:14-17.

13. Boncz I, Sebestyen A, Pinter I, et al. Age-group specific gap between treatment cost of and mortality due to breast and colorectal cancer. J Clin Oncol. 2007;25:4501-4502.

14. Brodszky V, Bálint P, Géher P, et al. Disease burden of psoriatic arthritis compared to rheumatoid arthritis, Hungarian experiment. Rheumatol Int. 2009 [Epub ahead of print].

15. Brodszky V, Czirják L, Géher P, et al. Rituximab in patients with rheumatoid arthritis: Systematic review. Orv Hetil. 2007;148:1883-1893.

16. Brodszky V, Pentek M, Gulacsi L. Efficacy of adalimumab, etanercept, and infliximab in psoriatic arthritis based on ACR50 response after 24 weeks of treatment. Scand J Rheumatol. 2008;37:399-400.

17. Drummond MF, Iglesiasc CP, Cooper NJ. Systematic reviews and economic evaluations conducted for the National Institute for Health and Clinical Excellence in the United Kingdom: A game of two halves? Int J Technol Assess Health Care. 2008;24:146-150.

18. Drummond MF, Schwartz JS, Jönsson B, et al. Key principles for the improved conduct of health technology assessments for resource allocation decisions. Int J Technol Assess Health Care. 2008;24:244-258.

19. Gulácsi L. The time for cost-effectiveness in the new European Union member states: The development and role of health economics and technology assessment in the mirror of the Hungarian experience. Eur J Health Econ. 2007;8:8388.

20. Gulácsi L, Boncz I, Drummond M. Issues for countries considering introducing the "fourth hurdle": The case of Hungary. Int J Technol Assess Health Care. 2004;20:337-341.

21. Gulácsi L, Brodszky V, Péntek M, et al. History of health technology assessment in Hungary. Int J Technol Assess Health Care. 2009;25(Suppl 1):120-126.

22. Gulácsi L, David T, Dózsa Cs. Pricing and reimbursement of drugs and medical devices in Hungary. Eur J Health Econ. 2002;3:271-278.

23. Gutiérrez-Ibarluzea I, Asua J, Latorre K. Policies of screening for colorectal cancer in European countries. Int J Technol Assess Health Care. 2008;24:270-276.

24. Jonsson E, Reiser SJ. The history of the International Journal of Technology Assessment in Health Care. Int J Technol Assess Health Care. 2009;25(Suppl 1):11-18.

25. Kovács A, Döbróssy L, Budai A, Boncz I, Cornides Á. Cervical screening in Hungary: Why does the "English model" work but the "Hungarian model" does not? Eur J Gynaecol Oncol. 2008;29:5-9.

26. Mühlberger N, Sroczynski G, Esteban E, et al. Costeffectiveness of primarily human papillomavirus-based cervical cancer screening in settings with currently established Pap screening: A systematic review commissioned by the German Federal Ministry of Health. Int J Technol Assess Health Care. 2008;24:184-192.

27. Péntek M, Horváth Cs, Boncz I, et al. Epidemiology of osteoporosis related fractures in Hungary by the nationwide health insurance database, 1999-2003. Osteoporos Int. 2008;19:243249.

28. Péntek M, Kobelt M, Czirják L, et al. Cost of rheumatoid arthritis in Hungary. J Rheumatol. 2007;34:14-37.

Krisztián Kárpáti, MPharm, PhD student

(kkaarpaatii@yahoo.com)

Doctoral School

Semmelweis Unversity

Üllói út 26.

H-1085, Budapest, Hungary

Assistant Professor

Health Economics and Technology Assessment

Research Centre

Corvinus University of Budapest

Fóvám tér 8.

H-1098, Budapest, Hungary

János Sándor, MD PhD

(janos.sandor@med.unideb.hu)

Associate Professor, Head of Division

Division of Biostatistics and Epidemiology

Department of Preventive Medicine

University of Debrecen

Kassai út 26

H-4028 Debrecen

Hungary 